\title{
Influence of Different Phosphorus Fertilization Levels and Sowing Date on Yield and Phosphorus Uptake by Corn
}

\author{
S.G. AL-Solaimani \\ Arid Land Agric. Dept., Faculty of Meteorology, Environment and \\ Arid Land Agriculture, King Abdulaziz University, Jeddah, Saudi Arabia
}

\begin{abstract}
This research studied the influence of different phosphorus fertilization rates $\left(0,50,100,150,200,250,300\right.$ and $350 \mathrm{~kg} \mathrm{P}_{2} \mathrm{O}_{5 /}$ ha $)$ and different sowing dates $\left(S_{1}=21-9-1993\right.$ and $\left.S_{2}=21-2-1994\right)$ on the total dry matter yield and its components (grain, ear and stover), grain protein contents, weight of 1000 grains, harvest index, shelling percentage and ear characters and components of corn plant (Giza 2 cultivar). The accumulation of phosphorus in soil was also investigated. Total dry matter yield and its components, 1000 grains weight, harvest index, shelling percentage, ear dry matter and volume, weight of grains/ear and phosphorus uptake were higher in sowing data $S_{1}$ than sowing date $S_{2}$. However, weight of cob/ear and number of rows/ear were higher in $S_{1}$ and $S_{2}$. The rest of characters and components were not affected by sowing date. Total dry matter yield and its components such as grains ears and stovers were significantly increased by the addition of $100 \mathrm{~kg} \mathrm{P}_{2} \mathrm{O}_{5} / \mathrm{ha}$. On the other hand phosphorus uptake by corn plant was significantly increased by the addition of $150 \mathrm{~kg} \mathrm{P}_{2} \mathrm{O}_{5} /$ ha. However, protein content of grain, the weight of 1000 grains, harvest index and shelling percentage were not affected by phosphorus application rates. Total phosphorus content of soil increased with increasing phosphorus application rates.
\end{abstract}

\section{Introduction}

Phosphorus is one of the most important nutrient on plant vegetative growth and on total dry matter yield and its components. Thus, the effect of phosphorus fertilizer on corn productivity was studied by many scientists. Barreto and Serpa (1986) studied the performance of corn and beans (Phaseolus vulgaris L.) under the influence of phosphate fertilization up to $300 \mathrm{~kg} \mathrm{P}_{2} \mathrm{O}_{5} / \mathrm{ha}$, and obtained the same amount of plant tissue phosphorus content by both species. Jiang et al. (1986), studied the response of corn yield to the application rate of phosphate fertilizers on calcareous soils. They found that phosphate application 60-90 $\mathrm{kg} \mathrm{P}_{2} \mathrm{O}_{5} /$ ha rates gave a yield increase of 29-36\% in corn. Borges and Mello (1987), studied the effect of phosphorus application on corn (Zea mays L.) on soils originally covered by cerrado vegetation which was given $0,150,300,600$ or 
$1200 \mathrm{~kg} \mathrm{P} \mathrm{O}_{5} / \mathrm{ha}$ as rock phosphate and in the following year 0,50,100 or $200 \mathrm{~kg}_{2} \mathrm{O}_{5} /$ ha as triple superphosphate was banded. There was no significant response in grain yield to rock phosphate in the 1st year but in the 2nd year there was significant response. Triple superphosphate gave a significant effect where yields increased from $1.47 \mathrm{t} / \mathrm{ha}$ with no triple superphosphate to $4.77 \mathrm{t} / \mathrm{ha}$ with the highest rate $\left(200 \mathrm{~kg} \mathrm{P}_{2} \mathrm{O}_{5} / \mathrm{ha}\right)$.

Singh et al. (1987) found a significant effects of the applying 0-75 $\mathrm{kg} \mathrm{P}_{2} \mathrm{O}_{5} / \mathrm{ha}$ on grain yield of four corn genotypes grown for two successive seasons. The application of $50 \mathrm{~kg} \mathrm{P}_{2} \mathrm{O}_{5}$ /ha to "Suwan" (growth period 105-110 days) and $25 \mathrm{~kg} \mathrm{P}_{2} \mathrm{O}_{5}$ /ha to "Diara Composite" gave the highest yield of 5.01 and $2.61 \mathrm{t} / \mathrm{ha}$ respectively as compared with respective yields of 4.25 and $2.18 \mathrm{t} /$ ha without $\mathrm{P}$. In the winter season, hybrid " $\mathrm{H}$ starch" and "Lakshmi" cultivar gave almost similar yields of 4.46-4.47 t/ha without $\mathrm{P}$ and 5.91-6.21 t/ha with $50 \mathrm{~kg} \mathrm{P}_{2} \mathrm{O}_{5} / \mathrm{ha}$. Hi-starch and Lakshmi gave yields of 7.18 and $6.37 \mathrm{t} /$ ha respectively with $75 \mathrm{~kg} \mathrm{P}_{2} \mathrm{O}_{5} /$ ha. Drover and Williams (1986) studied the response of annual crops of P-hungry soils to rock phosphate, they found that rock phosphate and superphosphate effects were additive and yield of annual crops ranged from $1.83 \mathrm{t} / \mathrm{ha}$ with no added $\mathrm{P}$ to $8.22 \mathrm{t} / \mathrm{ha}$ with $30 \mathrm{~kg}$ superphosphate $-\mathrm{P} / \mathrm{ha}$. Phosphorus (on dry matter basis) in ear leaves ranged from $0.16 \%$ without $\mathrm{P}$ fertilizer to $0.38 \%$ with $30 \mathrm{~kg}$ superphosphate - P/ha. On the other hand, Nader and Faught (1984), Neamtu and Ichim (1982), Mohammed et al. (1988) and Khakhar (1980), obtained an increase in corn grain yield when phosphorus and nitrogen were applied at rates $20 \mathrm{~kg}$ P/ha with 52 $\mathrm{kg} \mathrm{N} / \mathrm{ha}$ and $128 \mathrm{~kg}$ P/ha with $128 \mathrm{~kg} \mathrm{~N} / \mathrm{ha}$ and $100 \mathrm{~kg} \mathrm{P} / \mathrm{ha}$ with $150 \mathrm{~N} / \mathrm{ha}, 60 \mathrm{~kg} \mathrm{P} / \mathrm{ha}$ with $160 \mathrm{~kg} / \mathrm{N}$. On the other hand Khakar (1980), found an increase in the weight of 1000 grains with increase in phosphorus fertilization from 0 to $60 \mathrm{~kg} \mathrm{P}_{2} \mathrm{O}_{5} / \mathrm{ha}$. However, Getmanets et al. (1981), Hera et al. (1986), Mate and Ciobanu (1985), and Nagrila et al. (1987) found an increase in grain yield of corn with application of phosphorus added with nitrogen at the rates $90 \mathrm{~kg} \mathrm{P}_{2} \mathrm{O}_{5} / \mathrm{ha}, 160 \mathrm{~kg} \mathrm{P}_{2} \mathrm{O}_{5} / \mathrm{ha}, 150 \mathrm{~kg} \mathrm{P}_{2} \mathrm{O}_{5} / \mathrm{ha}$ and $120 \mathrm{~kg} \mathrm{P}_{2} \mathrm{O}_{5} /$ ha respectively.

Many questions arise that need answers about the optimum rate of phosphorus fertilizer and sowing date on corn yield and quality. Since fertilizers are highly economic agricultural inputs, it is necessary to determine the optimum economical rate for sensible productivity. Due to the lack of information concerning this field crop in the western region of the Kingdom of Saudi Arabia and due to the importance of this crop in the area, this research was purposed to study the influence of phosphorus fertilizer and sowing date on corn productivity, yield components and phosphorus uptake.

\section{Materials and Methods}

This research studied the production of corn plant (Giza 2 cultivar), under the influence of different phosphorus rates. A two field experiment was conducted at the agricultural research station of King Abdulaziz University at Hada-Alsham area during two sowing dates $\left(S_{1}=21-9-1993\right.$ and $\left.S_{2}=21-2-1994\right)$ to study the effect of different phosphorus rates application $\left(0,50,100,150,200,250,300\right.$ and $350 \mathrm{~kg} \mathrm{P}_{2} \mathrm{O}_{5} /$ ha) on yield characteristic and phosphorus uptake of corn plant. The two experiment were grown on the same site. The accumulation of phosphorus in soil was also investigated. Table (1) 
illustrates the climatic conditions recorded by the Faculty of Meteorology of King Abdulaziz University. These data included mean temperature degrees (minimum, maximum and average) and mean relative humidity for each sowing date.

TABLE 1. Monthly recorded temperature and humidity of the study area during the two sowing dates of the corn experiment.

\begin{tabular}{|c|c|c|c|c|c|c|c|c|c|c|c|c|c|}
\hline \multirow{3}{*}{ Month } & \multicolumn{6}{|c|}{ First sowing date (21.9.1993) } & \multirow{3}{*}{ Month } & \multicolumn{6}{|c|}{ Second sowing date (21.2.1994) } \\
\hline & \multicolumn{3}{|c|}{ Temperature (c) } & \multicolumn{3}{|c|}{ Humidity (\%) } & & \multicolumn{3}{|c|}{ Temperature (c) } & \multicolumn{3}{|c|}{ Humidity (\%) } \\
\hline & Min. & Max. & Mean & Min & Max. & Mean & & Min. & Max. & Mean & Min. & Max. & Mean \\
\hline August & 21 & 47 & 34 & 22 & 87 & 54.5 & February & 10.8 & 34 & 22.4 & 22 & 99 & 60.5 \\
\hline September & 22 & 46.2 & 34.1 & 21 & 99 & 60 & March & 10 & 35 & 22.5 & 22 & 99 & 90.5 \\
\hline October & 16.7 & 42 & 29.35 & 23 & 99 & 61 & April & 8 & 38.2 & 23.1 & 20 & 99 & 59.5 \\
\hline November & 14.2 & 36.5 & 25.35 & 27 & 99 & 63 & May & 14.8 & 42.8 & 28.8 & 23 & 99 & 61 \\
\hline
\end{tabular}

Four random samples of surface soil $(0-30 \mathrm{~cm})$ were collected from the open field of the experiment. The samples were mixed together to make one representative sample, it was air dried, passed through a 20-mesh sieve, placed in tied plastic bag. From this sample, small portion of soil was used for some physical and chemical analysis. The soil texture was determined by the hydrometer procedure as described by Day (1956) at $25^{\circ} \mathrm{C}$ using pyrophosphate as a dispersing agent. The result of soil texture analysis is presented in Table (2). Soil $\mathrm{pH}$ and EC were determined in soil to water ratio of 1:1 (w:v) using a glass electrode. Total organic matter (OM \%) in the soil was determined by Jakson's (1973) method.

TABLE 2. Soil texture of Hada-Al Sham experimental site.

\begin{tabular}{|c|c|c|c|}
\hline \multicolumn{3}{|c|}{ Particle size distribution \% } & \multirow{2}{*}{ Soil texture } \\
\hline Sand & Silt & Clay & \\
\hline 78 & 12 & 10 & Sandy loam \\
\hline
\end{tabular}

Total nitrogen was determined according to Bremner (1965). Nitrogen content was measured using a KJELTEC AUTO 1030 analyzer. Total phosphorus and potassium was determined after being extracted using the perchloric-nitric digestion procedure of Shelton and Harper (1941). Phosphorus content was quantified at $640 \mathrm{~nm}$ wavelength using a Turner spectro-photometer (Model 2000). The concentration of total potassium in the extract was measured by flame photometer (Corning 400). The result of the soil analysis are shown in Table (3).

Each of the two sowing date was conducted in randomized complete block design with three replication. In conducting the experiments the site was ploughed, leveled and then divided into 24 plots $(6 \times 10 \mathrm{~m})$, and each plot was divided into 12 rows, $75 \mathrm{~cm}$ a part. Planting pits within each row were spaced $30 \mathrm{~cm}$ a part, and 3 seeds were sown in each pip. The emerging seedlings were later thinned to one plant per hole. The different experimental doses of P-fertilizer (Triple super phosphate $46 \% \mathrm{P}_{2} \mathrm{O}_{5}$ ) under study and potassium sulfate $\left(50 \% \mathrm{~K}_{2} \mathrm{O}\right.$ at a rate of $400 \mathrm{~kg} \mathrm{~K}_{2} \mathrm{O} /$ ha were mixed with the soil. 
TABLE 3. Initial analysis for experimentalsite at Hada-Al Sham.

\begin{tabular}{|c|c|c|c|c|c|}
\hline & & & \multicolumn{3}{|c|}{ Total amount of } \\
\cline { 4 - 6 } $\begin{array}{c}\text { Soil } \\
\mathrm{pH}\end{array}$ & $\begin{array}{c}\text { Soil EC } \\
\left(\mathrm{m} \cdot \mathrm{mos} \mathrm{cm} \mathrm{cm}^{-1}\right)\end{array}$ & $\begin{array}{c}\text { Organic } \\
\text { matter } \%\end{array}$ & $\mathrm{~N}$ & $\mathrm{P}$ & $\mathrm{K}$ \\
\cline { 4 - 6 } & & & \multicolumn{3}{|c|}{$\mathrm{g} \mathrm{kg}^{-1}$} \\
\hline 8.2 & 0.69 & 0.49 & 0.4 & 0.113 & 2.3 \\
\hline
\end{tabular}

The urea $(46 \% \mathrm{~N})$ at a rate of $400 \mathrm{~kg} / \mathrm{ha}$ were applied side dressed at four equal intervals of 2 weeks each during the growth period. In this respect the first dose was given 15 days after planting whereas the last dose was applied 60 days after planting. After that the experimental land received the sowing irrigation. The irrigation were carried out according to the crop water requirement.

At the end of the experiment, the whole crop was harvested, and total weight of 100 residual stover and weight of grains in 100 ears were measured for each plot. In addition total dry matter yield and its components $(\mathrm{kg} / \mathrm{ha})$, harvest index and shelling percentage were also estimated. Five ears from each plot were harvested and their mean length, diameter, and volume, number of grains/row, number of grains/ear, number of rows/ear, the mean weight of ear and its components (grains and cob), weight of 1000 grains and protein content of grains were also recorded. Statistical analysis was performed using the M-state program.

\section{Results and Discussion}

\section{Ear Character and Components}

The ear diameter and volume, weight of grain/ear $(\mathrm{P}=0.01)$, number of rows/ear and weight of cob/ear $(\mathrm{P}=0.05)$, were significantly affected by sowing date. The weight of cob/ear was affected by the interactions of sowing date with phosphorus treatment (Table 4).

TABLE 4. Summary of analysis of variance for ear characters and components of the two successive yields of corn plant.

\begin{tabular}{|c|c|c|c|c|c|c|c|c|c|}
\hline \multirow[b]{2}{*}{ Source } & \multirow[b]{2}{*}{ D.F. } & \multicolumn{8}{|c|}{ Ear characters and components } \\
\hline & & $\begin{array}{l}\text { Ear length } \\
\quad(\mathrm{cm})\end{array}$ & $\begin{array}{c}\text { Ear diameter } \\
(\mathrm{cm})\end{array}$ & $\begin{array}{l}\text { Ear volume } \\
\quad(\mathrm{cm} 3)\end{array}$ & $\begin{array}{l}\text { Number of } \\
\text { rows / ear }\end{array}$ & $\begin{array}{l}\text { Number of } \\
\text { grains / ear }\end{array}$ & $\begin{array}{l}\text { Number of } \\
\text { grains / row }\end{array}$ & $\begin{array}{l}\text { Weight of } \\
\text { grains / ear }\end{array}$ & $\begin{array}{l}\text { Weight of } \\
\text { cob/ ear }\end{array}$ \\
\hline S & 1 & 0.209 & $0.000^{* *}$ & $0.000^{* *}$ & $0.024^{*}$ & 0.273 & - & $0.000^{* *}$ & $0.019^{*}$ \\
\hline $\mathrm{P}$ & 7 & 0.175 & 0.432 & - & - & - & - & 0.113 & 0.306 \\
\hline S.P. & 7 & 0.261 & 0.421 & - & 0.232 & - & - & 0.158 & $0.040^{*}$ \\
\hline E.M.S. & 30 & 0.704 & 0.045 & 2151.848 & 0.816 & 3446.983 & 11.525 & 176.538 & 19.58 \\
\hline
\end{tabular}

$\mathrm{S}=$ Sowing date

$\mathrm{P}=$ Phosphorus treatments

E.M.S. $=$ Error mean square
D.F. = Degree of freedom

*Significance at 0.05 level

** Significance at 0.01 level 
Ear diameter and volume, weight of grains/ear were higher in sowing date $S_{1}$ than sowing date $S_{2}$. Number of rows/ear, and weight of cob/ear were higher in $S_{2}$ and $S_{1}$. Ear length, number of grains/ear and number of rows/ear were not affected by sowing date (Table 5). On the other hand, ear characters and components were not affected by phosphorus treatments (Table 5). This in contrast to the finding of Getmanets et al. (1981), Hera et al. (1986), Mate and Ciobanu (1985) and Cieko et al. (1982). Temchenko et al. (1986) found an increase in grain protein content with increase in phosphorus fertilizers rates.

TABLE 5. Means of ear characters and components and their significance test for corn plant experiment.

\begin{tabular}{|c|c|c|c|c|c|c|c|c|c|}
\hline & \multicolumn{8}{|c|}{ Ear character and components } \\
\hline & & $\begin{array}{l}\text { Ear length } \\
\quad(\mathrm{cm})\end{array}$ & $\begin{array}{l}\text { Ear diameter } \\
(\mathrm{cm})\end{array}$ & $\begin{array}{l}\text { Ear volume } \\
\quad(\mathrm{cm} 3)\end{array}$ & $\begin{array}{l}\text { Number of } \\
\text { rows / ear }\end{array}$ & $\begin{array}{l}\text { Number of } \\
\text { grains / ear }\end{array}$ & $\begin{array}{l}\text { Number of } \\
\text { grains / row }\end{array}$ & $\begin{array}{l}\text { Weight of } \\
\text { grains / ear }\end{array}$ & $\begin{array}{l}\text { Weight of } \\
\text { cob / ear }\end{array}$ \\
\hline & S1 & $15.492 \mathrm{~A}$ & $5.324 \mathrm{~A}$ & $343.77 \mathrm{~A}$ & $13.30 \mathrm{~B}$ & $406.75 \mathrm{~A}$ & $30.87 \mathrm{~A}$ & $139.15 \mathrm{~A}$ & $26.95 \mathrm{~B}$ \\
\hline & S2 & $15.008 \mathrm{~A}$ & $4.935 \mathrm{~B}$ & $288.15 \mathrm{~B}$ & $13.91 \mathrm{~A}$ & $425.65 \mathrm{~A}$ & $30.85 \mathrm{~A}$ & $97.91 \mathrm{~B}$ & $30.12 \mathrm{~A}$ \\
\hline \multicolumn{2}{|c|}{ L.S.D. } & 0.53 & 8.63 & 18.93 & 0.36 & 23.96 & 1.38 & 5.42 & 1.8 \\
\hline & PO & $15.34 \mathrm{~A}$ & $5.17 \mathrm{~A}$ & $324.05 \mathrm{~A}$ & $13.97 \mathrm{~A}$ & $373.67 \mathrm{~A}$ & $30.07 \mathrm{~A}$ & $117.60 \mathrm{~A}$ & $31.70 \mathrm{~A}$ \\
\hline & P1 & $15.13 \mathrm{~A}$ & $5.01 \mathrm{~A}$ & $302.13 \mathrm{~A}$ & $13.17 \mathrm{~A}$ & $402.00 \mathrm{~A}$ & $30.70 \mathrm{~A}$ & $118.37 \mathrm{~A}$ & $30.03 \mathrm{~A}$ \\
\hline & $\mathrm{P} 2$ & $14.17 \mathrm{~A}$ & $5.22 \mathrm{~A}$ & $315.88 \mathrm{~A}$ & $13.87 \mathrm{~A}$ & $433.73 \mathrm{~A}$ & $30.40 \mathrm{~A}$ & $125.17 \mathrm{~A}$ & $29.17 \mathrm{~A}$ \\
\hline \multirow[t]{5}{*}{$\mathrm{P}$} & $\mathrm{P} 3$ & $15.20 \mathrm{~A}$ & $5.13 \mathrm{~A}$ & $329.27 \mathrm{~A}$ & $13.23 \mathrm{~A}$ & $418.57 \mathrm{~A}$ & $32.50 \mathrm{~A}$ & $123.43 \mathrm{~A}$ & $27.83 \mathrm{~A}$ \\
\hline & P4 & $16.50 \mathrm{~A}$ & $5.09 \mathrm{~A}$ & $328.52 \mathrm{~A}$ & 13.90 & $435.80 \mathrm{~A}$ & $31.10 \mathrm{~A}$ & $122.47 \mathrm{~A}$ & $28.63 \mathrm{~A}$ \\
\hline & P5 & $15.80 \mathrm{~A}$ & $5.25 \mathrm{~A}$ & $332.25 \mathrm{~A}$ & $14.00 \mathrm{~A}$ & $448.50 \mathrm{~A}$ & $32.80 \mathrm{~A}$ & $125.93 \mathrm{~A}$ & $29.33 \mathrm{~A}$ \\
\hline & P6 & $14.87 \mathrm{~A}$ & $5.02 \mathrm{~A}$ & $295.58 \mathrm{~A}$ & $13.40 \mathrm{~A}$ & $412.30 \mathrm{~A}$ & $30.93 \mathrm{~A}$ & $105.97 \mathrm{~A}$ & $25.93 \mathrm{~A}$ \\
\hline & P7 & $14.33 \mathrm{~A}$ & $5.15 \mathrm{~A}$ & $300.03 \mathrm{~A}$ & $13.33 \mathrm{~A}$ & $405.07 \mathrm{~A}$ & $28.43 \mathrm{~A}$ & $109.33 \mathrm{~A}$ & $25.70 \mathrm{~A}$ \\
\hline \multicolumn{2}{|c|}{ L.S.D. } & 2.398479 & 0.250126 & 54.69642 & 1.065119 & 69.2265 & 4.002889 & 15.66651 & 5.21746 \\
\hline
\end{tabular}

Sowing date $\mathrm{S} 1=(21.9 .1993)$

$\mathrm{S} 2=(21.2 .1994)$

L.S.D. $=$ Least significant difference at 0.05

$$
\begin{aligned}
& \text { Phosphorus treatments }(\mathrm{kg} / \mathrm{ha}) \\
& \mathrm{PO}=0 \mathrm{~kg} \mathrm{P}_{2} \mathrm{O}_{5} / \mathrm{ha} \\
& \mathrm{P} 1=50 \mathrm{~kg} \mathrm{P}_{2} \mathrm{O}_{5} / \mathrm{ha} \\
& \mathrm{P} 2=100 \mathrm{~kg} \mathrm{P}_{2} \mathrm{O}_{5} / \mathrm{ha} \\
& \mathrm{P} 3=150 \mathrm{~kg} \mathrm{P}_{2} \mathrm{O}_{5} / \mathrm{ha}
\end{aligned}
$$

Means within a column for each character followed by the same letter are not significantly different at the $5 \%$ level using LSD test.

The weight of cob was decreased with increasing phosphorus rates with $\mathrm{S}_{2}$ dominating $S_{1}$ (Fig. 1).

\section{Total Dry Matter Yield and its Characters}

The total dry matter yield and its components (grain, ear and stover), weight of 1000 grains, harvest index and shelling percentage were significantly affected by sowing date, while phosphorus application significantly affected grain, ear and total dry matter $(\mathrm{P}=0.01)$ (Table 6). 


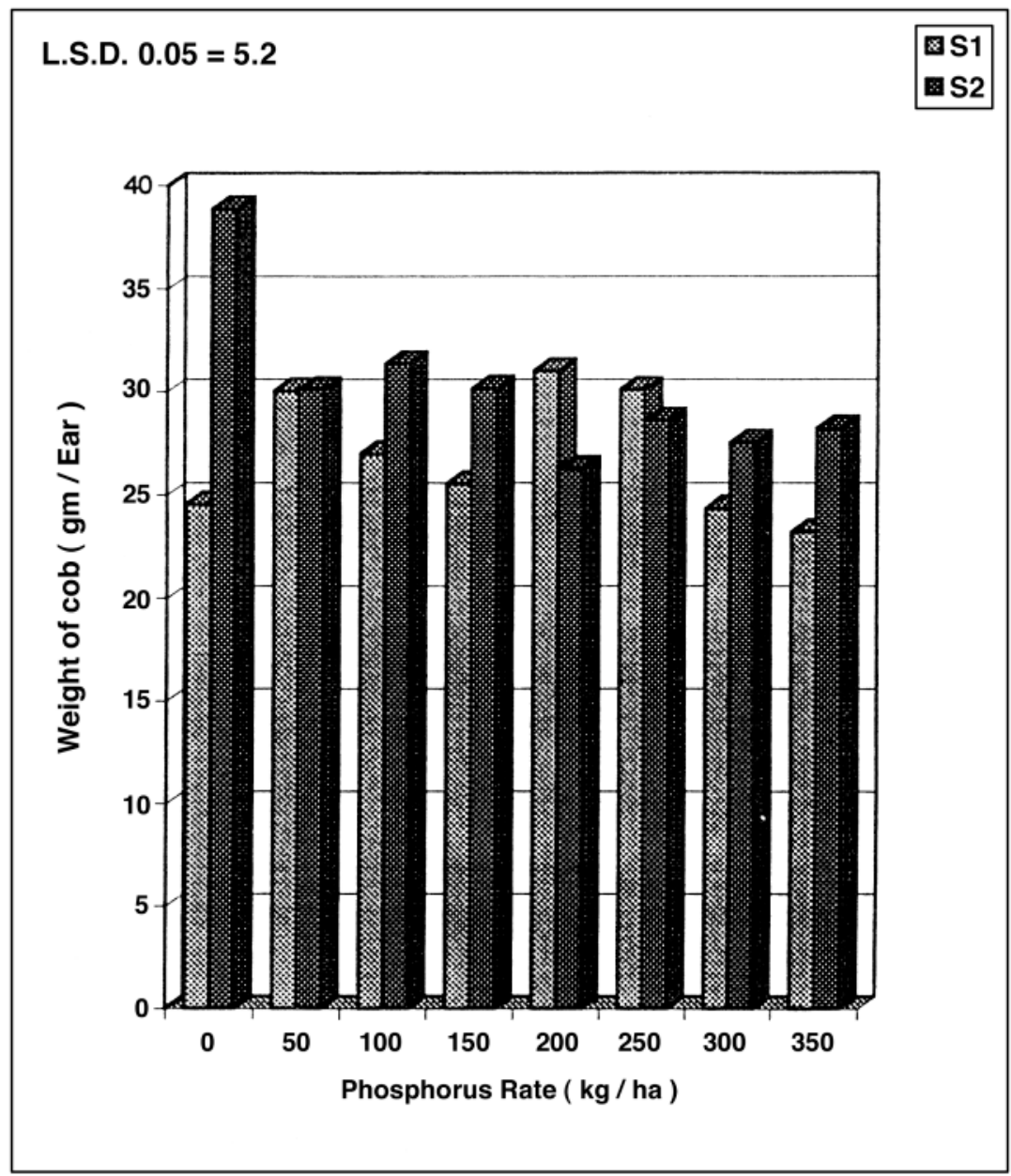

\section{Sowing Date S1 = 21.9.1993 Sowing Date S2 = 21.2.1944}

Fig. 1. Effect of different rates of phosphorus on weight of cob of two successive crops of corn plant. 
TABLE 6. Summary of analysis of variance for yield characters and components of the two succesive yields of corn plant.

\begin{tabular}{|c|c|c|c|c|c|c|c|c|c|c|}
\hline \multirow{2}{*}{ Source } & \multirow{2}{*}{ D.F. } & \multicolumn{4}{|c|}{ Dry matter yield (kg / ha) } & \multirow{2}{*}{$\begin{array}{c}\text { Phosphorus } \\
\text { uptake } \\
(\mathrm{kg} / \mathrm{ha})\end{array}$} & \multirow{2}{*}{$\begin{array}{c}\text { Protein } \\
\text { content of } \\
\text { grains }(\%)\end{array}$} & \multirow{2}{*}{$\begin{array}{c}1000 \text { Grains } \\
\text { weight } \\
\text { (grain index) }\end{array}$} & \multirow{2}{*}{$\begin{array}{l}\text { Harvest } \\
\text { index }\end{array}$} & \multirow{2}{*}{$\begin{array}{l}\text { Shelling } \\
\text { percentage }\end{array}$} \\
\hline & & Grain & Ear & Stover & Total & & & & & \\
\hline S & 1 & $0.000^{* *}$ & $0.000^{* *}$ & $0.001^{* *}$ & $0.000^{* *}$ & $0.021^{*}$ & 0.258 & $0.000^{* *}$ & $0.000^{* *}$ & $0.000 * * *$ \\
\hline $\mathrm{P}$ & 7 & $0.000^{* *}$ & $0.000^{* *}$ & 0.171 & $0.002^{* *}$ & $0.016^{*}$ & 0.209 & - & - & 0.226 \\
\hline S.P. & 7 & 0.266 & 0.231 & - & - & $0.000^{*}$ & - & 0.275 & - & 0.396 \\
\hline E.M.S. & 30 & 486402.7 & 913231.9 & 1373932.2 & 3182638.1 & 0.548 & 6.811 & 188.781 & 19.789 & 20.4 \\
\hline
\end{tabular}

$\mathrm{S}=$ Sowing date

$\mathrm{P}=$ Phosphorus treatments

E.M.S. $=$ Error mean square

Total dry matter yield and its components such as grain, ear and stover, weight of 1000 grains, harvest index and shelling percentage were higher in sowing date $S_{1}$ than sowing date $S_{2}$ (Table 7). Differences in the environmental conditions of sowing date $S_{1}$ and $S_{2}$ in term of temperature (Table 1), (Mack et al. 1966) and light intensity (Leonard and Martin, 1963) might had contributed to the differences observed on total dry matter yield and its components. The total dry matter and its components such as grain, ear and stover were significantly increased by the addition of $100 \mathrm{~kg} \mathrm{P}_{2} \mathrm{O}_{5} / \mathrm{ha}$. There was no significant difference between $\left(\mathrm{P}_{2}-\mathrm{P}_{7}\right)\left(\mathrm{P}_{2} 100-\mathrm{P}_{7} 350 \mathrm{~kg} \mathrm{P}_{2} \mathrm{O}_{5} / \mathrm{ha}\right)$ (Table 7). Similar results were obtained by the following authors: Jiang et al. (1986), Singh et al. (1987) and Drover and Williams (1986).

TABLE 7. Means of yield characters and components and their significance test for corn plant experiment.

\begin{tabular}{|c|c|c|c|c|c|c|c|c|c|c|}
\hline \multirow{2}{*}{} & \multicolumn{4}{|c|}{ Dry matter yield (kg/ha) } & $\begin{array}{c}\text { Phosphorus } \\
\text { uptake } \\
(\mathrm{kg} / \mathrm{ha})\end{array}$ & $\begin{array}{c}\text { Protein } \\
\text { content of } \\
\text { grains (\%) }\end{array}$ & $\begin{array}{c}\text { 100 Grain } \\
\text { (grains index) }\end{array}$ & $\begin{array}{c}\text { Harvest } \\
\text { index }\end{array}$ & $\begin{array}{c}\text { Shelling } \\
\text { percentage }\end{array}$ \\
\cline { 2 - 12 } & Grain & Ear & Stover & Total & & & & & \\
\hline & S1 & $5824.43 \mathrm{~A}$ & $8403.45 \mathrm{~A}$ & $5922.5 \mathrm{~A}$ & $14325.96 \mathrm{~A}$ & $2.581 \mathrm{~A}$ & $7.29 \mathrm{~A}$ & $350.81 \mathrm{~A}$ & $43.71 \mathrm{~A}$ & $75.02 \mathrm{~A}$ \\
\hline & S2 & $2679.80 \mathrm{~B}$ & $4792.05 \mathrm{~B}$ & $4773.7 \mathrm{~B}$ & $9565.74 \mathrm{~B}$ & $2.348 \mathrm{~B}$ & $8.16 \mathrm{~A}$ & $241.91 \mathrm{~B}$ & $33.07 \mathrm{~B}$ & $66.83 \mathrm{~B}$ \\
\hline L.S.D. & 284.72 & 390.13 & 478.52 & 728.31 & 0.152 & 1.65 & 5.6 & 1.81 & 1.84 \\
\hline & P0 & $3275.77 \mathrm{~B}$ & $5118.46 \mathrm{~B}$ & $4233.06 \mathrm{C}$ & $9651.51 \mathrm{~B}$ & $1.523 \mathrm{D}$ & $7.11 \mathrm{~A}$ & $290.82 \mathrm{~A}$ & $36.08 \mathrm{~A}$ & $68.64 \mathrm{~A}$ \\
\hline & P1 & $3134.27 \mathrm{~B}$ & $5319.87 \mathrm{~B}$ & $4385.4 \mathrm{C}$ & $9705.3 \mathrm{~B}$ & $1.6 \mathrm{D}$ & $8.86 \mathrm{~A}$ & $295.68 \mathrm{~A}$ & $38.75 \mathrm{~A}$ & $72.53 \mathrm{~A}$ \\
\hline P & P2 & $4743.37 \mathrm{~A}$ & $6868.61 \mathrm{~A}$ & $5877.2 \mathrm{~B}$ & $12745.8 \mathrm{~A}$ & $2.174 \mathrm{C}$ & $9.20 \mathrm{~A}$ & $298.10 \mathrm{~A}$ & $37.22 \mathrm{~A}$ & $71.52 \mathrm{~A}$ \\
\hline & P3 & $4216.65 \mathrm{~A}$ & $6597.75 \mathrm{~A}$ & $5150.6 \mathrm{~B}$ & $11748.4 \mathrm{AB}$ & $2.732 \mathrm{~B}$ & $8.70 \mathrm{~A}$ & $304.37 \mathrm{~A}$ & $40.03 \mathrm{~A}$ & $72.71 \mathrm{~A}$ \\
\hline & P4 & $4504.00 \mathrm{~A}$ & $6736.65 \mathrm{~A}$ & $5533.8 \mathrm{~B}$ & $12270.4 \mathrm{~A}$ & $2.759 \mathrm{~B}$ & $7.80 \mathrm{~A}$ & $299.05 \mathrm{~A}$ & $40.55 \mathrm{~A}$ & $74.50 \mathrm{~A}$ \\
\hline & P5 & $4567.80 \mathrm{~A}$ & $7195.02 \mathrm{~A}$ & $5829.3 \mathrm{~B}$ & $13024.3 \mathrm{~A}$ & $2.837 \mathrm{AB}$ & $7.46 \mathrm{~A}$ & $295.22 \mathrm{~A}$ & $38.27 \mathrm{~A}$ & $69.46 \mathrm{~A}$ \\
\hline & P6 & $4663.83 \mathrm{~A}$ & $7264.47 \mathrm{~A}$ & $5957.2 \mathrm{~A}$ & $13221.6 \mathrm{~A}$ & $2.953 \mathrm{AB}$ & $7.61 \mathrm{~A}$ & $295.17 \mathrm{~A}$ & $37.73 \mathrm{~A}$ & $69.72 \mathrm{~A}$ \\
\hline
\end{tabular}


TABLE 7. Contd.

\begin{tabular}{|c|c|c|c|c|c|c|c|c|c|}
\hline & \multicolumn{4}{|c|}{ Dry matter yield (kg / ha) } & \multirow{2}{*}{$\begin{array}{c}\text { Phosphorus } \\
\text { uptake } \\
(\mathrm{kg} / \mathrm{ha}) \\
\end{array}$} & \multirow{2}{*}{$\begin{array}{l}\text { Protein } \\
\text { content of } \\
\text { grains (\%) }\end{array}$} & \multirow{2}{*}{$\begin{array}{c}100 \text { Grain } \\
\text { weight } \\
\text { (grains index) }\end{array}$} & \multirow{2}{*}{$\begin{array}{c}\text { Harvest } \\
\text { index }\end{array}$} & \multirow{2}{*}{$\begin{array}{l}\text { Shelling } \\
\text { percentage }\end{array}$} \\
\hline & Grain & Ear & Stover & Total & & & & & \\
\hline P7 & $4911.28 \mathrm{~A}$ & $7681.17 \mathrm{~A}$ & $5518.1 \mathrm{AB}$ & $13199.2 \mathrm{~A}$ & $3.139 \mathrm{~A}$ & $5.09 \mathrm{~A}$ & $292.52 \mathrm{~A}$ & $38.54 \mathrm{~A}$ & $68.36 \mathrm{~A}$ \\
\hline L.S.D. & 822.3395 & 1126.792 & 1382 & 2103.52 & 0.3777 & 3.07722 & 16.20064 & 5.24523 & 5.325466 \\
\hline
\end{tabular}

$\begin{array}{cll}\text { Sowing date } \mathrm{S} 1=(21.9 .1993) & \text { Phosphorus treatments }(\mathrm{kg} / \mathrm{ha}) & \\ \mathrm{S} 2=(21.2 .1994) & \mathrm{PO}=0 \mathrm{~kg} \mathrm{P}_{2} \mathrm{O}_{5} / \mathrm{ha} & \mathrm{P} 4=200 \mathrm{~kg} \mathrm{P}_{2} \mathrm{O}_{5} / \mathrm{ha} \\ \text { L.S.D. = Least significant difference at } 0.05 & \mathrm{P} 1=50 \mathrm{~kg} \mathrm{P}_{2} \mathrm{O}_{5} / \mathrm{ha} & \mathrm{P} 5=250 \mathrm{~kg} \mathrm{P}_{2} \mathrm{O}_{5} / \mathrm{ha} \\ & \mathrm{P} 2=100 \mathrm{~kg} \mathrm{P}_{2} \mathrm{O}_{5} / \mathrm{ha} & \mathrm{P} 6=300 \mathrm{~kg} \mathrm{P}_{2} \mathrm{O}_{5} / \mathrm{ha} \\ & \mathrm{P} 3=150 \mathrm{~kg} \mathrm{P}_{2} \mathrm{O}_{5} / \mathrm{ha} & \mathrm{P} 7=350 \mathrm{~kg} \mathrm{P}_{2} \mathrm{O}_{5} / \mathrm{ha}\end{array}$

Means within a column for each character followed by the same letter are not significantly different at the $5 \%$ level using LSD test.

However, the weight of 1000 grains, harvest index, shelling percentage and protein content of grains were not affected by phosphorus rates (Table 7). Similar result was found by Ahmed et al. (1965) and Ibrahim et al. (1979). They did not observe any effect of phosphorus fertilizer rates on weight of 1000 grains. However, Khakar (1980), found an increase in the weight of 1000 grains with increasing in phosphorus fertilization from 0 to $60 \mathrm{~kg} \mathrm{P}_{2} \mathrm{O}_{5} / \mathrm{ha}$. Also, addition of phosphorus was found to increase protein content of leaves, stems and grain of corn as was found by Temchenko et al. (1986).

\section{Plant-Phosphorus Uptake}

Phosphorus uptake by corn plants was significantly affected by sowing date growth stage and phosphorus rate $(\mathrm{P}=0.05)$. The phosphorus uptake was significantly affected by the interaction of sowing date $\times$ growth stage and sowing date $\times$ phosphorus rate $(\mathrm{P}=0.01)$ (Table 6).

Phosphorus uptake was significantly higher in sowing date $S_{1}(2.581 \mathrm{~kg} / \mathrm{ha})$ than sowing date $\mathrm{S}_{2}(2.348 \mathrm{~kg} / \mathrm{ha}$ ) (Table 7$)$. The phosphorus uptake significantly increased by increasing phosphorus application rates. However, there were no significant differences between phosphorus rates $\mathrm{P}_{3}$ to $\mathrm{P}_{7}(150-350 \mathrm{~kg} / \mathrm{ha})$ which means that $150 \mathrm{~kg} / \mathrm{ha}$ was adequate to produce the highest phosphorus uptake by corn plant (Table 7). This result was in agreement with Sedlarska (1985), who reported that increasing rates of superphosphorus application gave an increase in phosphorus uptake from fertilizer. He concluded that in low phosphorus soils the increase in P uptake was partially linear with $\mathrm{P}$ application rate but was curve linear in high phosphorus soils. The rate pattern of phosphorus uptake followed closely that for total dry matter yield and its components

\section{Final Soil Analysis}

Total phosphorus content of soil at the end of the harvest (sowing date $S_{2}$ ) was significantly increased with increasing rates of phosphorus fertilization (Fig. 2). The significant effect of phosphorus fertilizer on yield ( $\mathrm{kg} / \mathrm{ha}$ ) and its components and phosphorus uptake $(\mathrm{kg} / \mathrm{ha})$ suggests that residual content of phosphorus in this soil was increased with increasing rates of phosphorus fertilization. Similar result was found by Brar et al. (1987), Patiram and Prasad (1991) and Webb et al. (1992). 


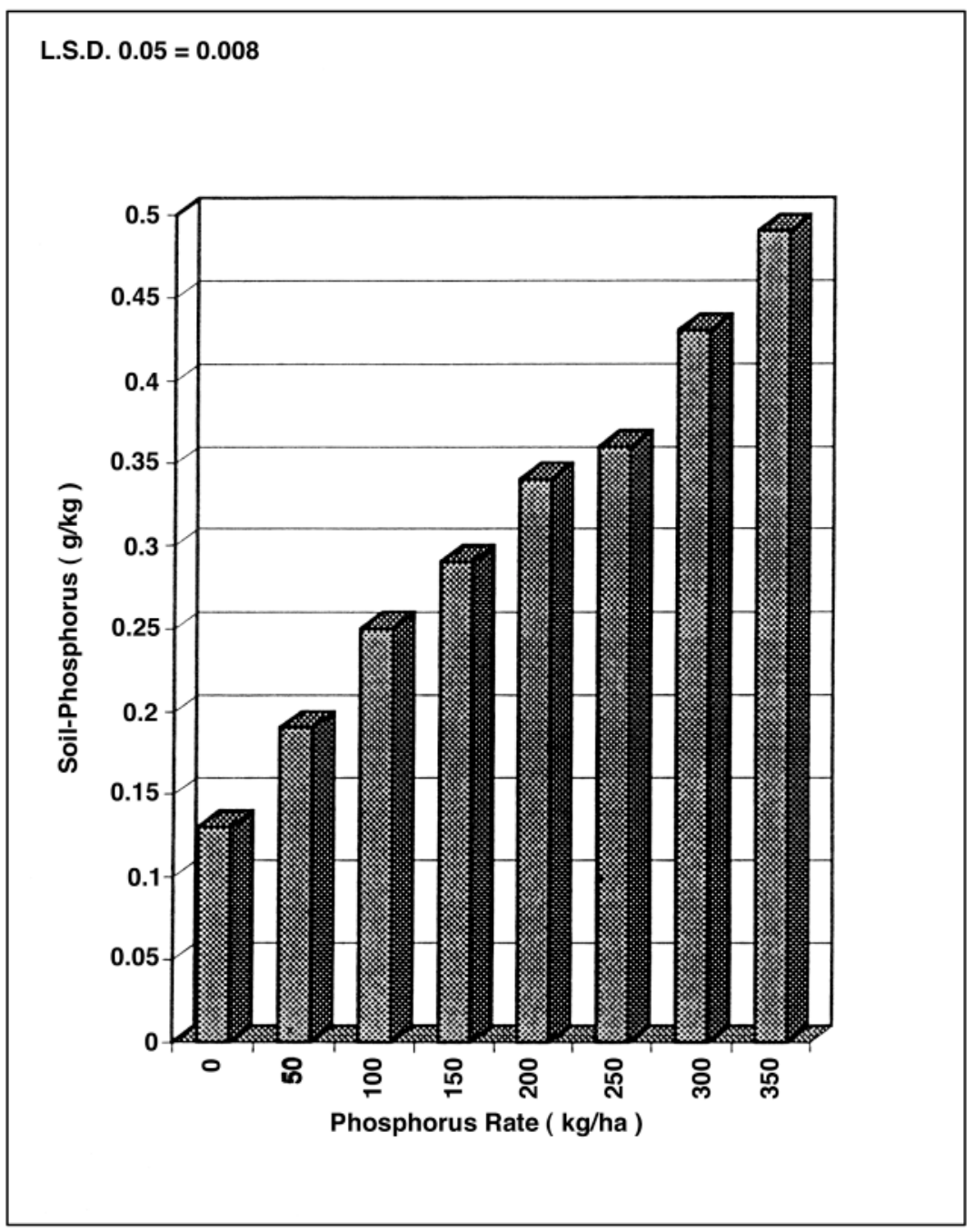

FIG. 2. Effect of different rates of phosphorus on the phosphorus content of soil under corn plant experiment. 


\section{References}

Ahmed, D.M., Raafat, A., Hussien, A.M. (1965) Studies on the nutrition of corn plant; I. The yield of hybrid corn plant in relation to different rates of $\mathrm{N}$ and $\mathrm{P}$ fertilizers under field conditions. Bull. Fac. Agric. Cairo Univ., XVI, I; 161-173.

Barreto, A.C. and Serpa, J.E.S. (1986) Performance of maize and beans (Phaseolus vulgaris L.) in separate or associated cropping systems, under the influence of phosphate fertilization. EMBRAPA, Brazil. No. 2, 9 p.

Borges, L.C.V. and Mello, F. de A.F. (1987) Application of phosphorus to crops of maize (Zea mays L.) on soils originally covered by cerrado vegetation. Agric. "Luiz de Queiroz" Escola Agron. 44(2): 11071132.

Brar, S.P.S., Shakti, and Bhajan Singh (1987) Utilization of native and applied phosphorus in maize-wheat cropping sequence. Indian Journal of Ecology 14(2): 236-244.

Bremner, M. (1965) Nitrogen availability indexes. In C.A. Blact et al. (ed.). Methods of Soil Analysis. Part 2 Agronomy 9: 1324-1345.

Ciecko, Z., Mazur, T. and Szylkiewicz, E. (1982) Studies of fertilizer application to crop grown in rotations on various soil complexes. II. Naukowe Akademii Rolniczo-Technicznej Wolsztynie. Rolnictwo No. 34: 69-82.

Day, R.A. (1956) Quantitative Analysis (3ed). Eaglewood Cliffs, N.J.: Prentice-Hall, Inc.

Drover, D.P., Williams, C.N. (1986) Using rock phosphate effectively for annual crops on P-hungry soils. Agriculture International 38(2): 56-58.

Getmanets, A. Ya., Telyatnikov, N.Ya., Chernyavskaya, N.A. and Evstafev, D.K. (1981) Effect of nitrogen nutrition level on yield, nutrient uptake and nutritive value of maize grain grown under irrigated conditions. Agrokhimiya No. 11: 3-9.

Hera, C., Idriceanu, H., Dobresu, E., Mihaila, V., Rusu, P., Chardes, D. and Pattakou, V. (1986) Nutritive interactions due to mineral fertilizer application and their influence on maize yield quality. Probleme de Agrofitotehnie Teoretica Si Aplicata 8(2): 171-181.

Ibrahim, A.a., Abdulgalil, A.A., Zeidan, E.M., Eraky, A.G. and Hamdan, B.Y. (1979) Locality effect on maize growth under different levels of NPK fertilizers. Zagazig J. Agric. Res. 6(1): 209-227.

Jackson, M.L. (1973) Soil Chemical Analysis. New Delhi, India; Prentice-Hall, India.

Jiang, B.F., Li, A.R. and Gu, Y.C. (1986) Investigations on the application rate of phosphate fertilizers in calcareous soils. Soils Inst. Soil Sci., Acad. Sci. 18(4): 186-188.

Khakar, R.T. (1980) Effect of nitrogen and phosphorous application on growth parameters and yield of hybrid maize-Ganga- 101 under rainfed conditions. J. of Maharashtra Agric. Univ. 5(3): 266-267.

Leonard, W.H. and Martin, J.H. (1963) Cereal Crops. p. 682, MacMillan Publishing Co., Inc., New York, NY.

Mack, H.J., Fane, Sc.C. and Apple Sr., S.B. (1966) Response of Snap Beans (Phaseolus vulgaris) to soil temperature and phosphorus fertilizer on five western oregon soils. SSSA Prpc. 30: 236-241.

Mate, S. and Ciobanu, C. (1985) The influence of fertilizers and rotations on yields and quality of irrigated maize. Analele Institutului de Cercetari pentru Cereal si Plante Tehnice Fundulea. 52: 207-222.

Mohammed, Shafiq, Zafar, M.I., Ikram, M. and Ranjha, A.Y. (1988) The influence of simulated soil erosion restorative fertilization on maize and wheat production. J. of Sci. and Ind. Res. 7: 502-505.

Nader, H.M. and Faught, W.A. (1984) Maize yield response to different levels of nitrogen and phosphorus fertilizer application: a seven season study. East African Agric. and Forestry J. 44 (Special issue) 147156.

Nagrila, M., Stan, S. and Negrila, E. (1987) Efficient mineral fertilizer applications for maize, soybeans and sunflowers on a cambic chernozem on the burnas plain. Probleme de Agrofitotehnie Teoretica si Aplicata. 9(2): 129-149.

Neamtu, T. and Ichim, T. (1982) Variation with time of maize production under the influence of fertilization and rotation on sloped lands. Cercetari Agron. in Moldova No. 4: 56-58.

Patiram, A.S. and Prasad, R.N. (1991) Growth of maize and phosphorus uptake in relation to phosphate adsorption characteristics of acid soils. J. Indian Soc. of Soil Sci. 39(2): 302-307.

Sedlarska, B. (1985) The direct and residual effect of fertilizers in uptake and consumption of nitrogen, phosphorus and potassium by irrigated maize in monoculture in southeastern Bulgaria. Rasteniov dni Nanki 22(2): 32-40. 
Shelton, W.R., Harper, H.J. (1941) A rapid method for the determination of total phosphorus in soil and plant material. Iowa State College J. of Sci. 15: 403-413.

Singh, A.K., Singh, B.K. and Singh, S.B. (1987) Response of maize genotypes to phosphorus in the Ganges diara of Bihar. Indian Journal of Agronomy. Operational Res. Project. 32(4): 446-447.

Temchenko, V.A., Klyusnikov, V.T., Vittsenko, V.P. and Bokan, V.S. (1986) Effect of phosphorus fertilizer on the nutrient regime of mycelial-calcareous chernozem and on the chemical composition and yield of maize. Agrokhimiya No. 5: 13-15.

Webb, J.R., Mallarino, A.P. and Blackmer, A.M. (1992) Effect of residual and annually applied phosphorus on soil values and yield of corn and soybean. J. Production Agric. 5(1): 148-152. 


\section{تأثير معدلات مختلفة من التسميد الفوسفوري وميعاد الزراعة على إنتاجية الذرة الشامية (Zea mays L.) وامتصاصه للفوسفور}

\section{سمير جميل السليماني}

كلية الأرصاد والبيئة وزراعة المناطق الجافـة ، جامعة الملك عبد العزيز

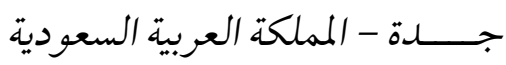



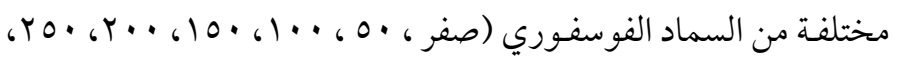

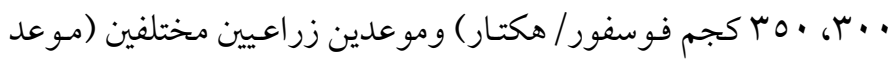

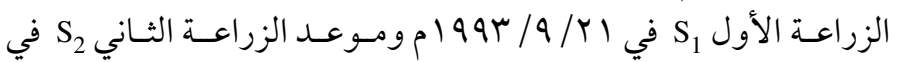

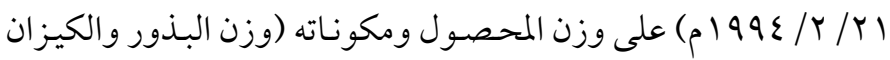

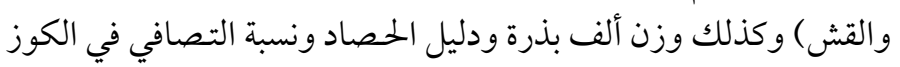

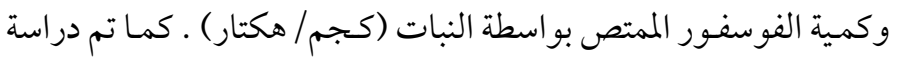

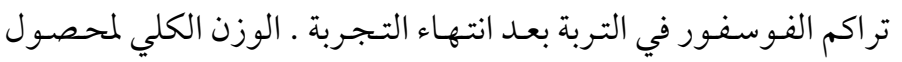

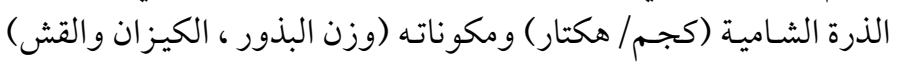

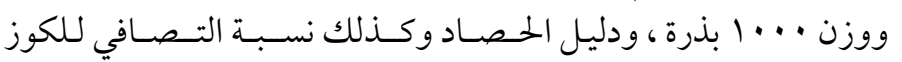

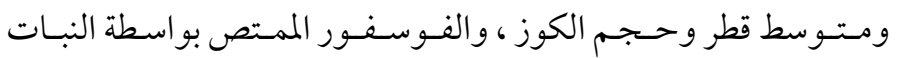

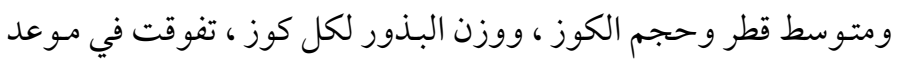

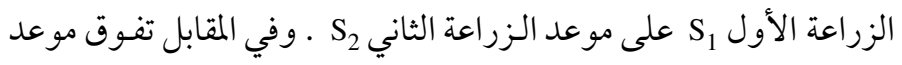

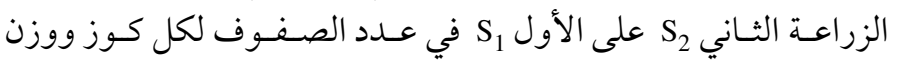

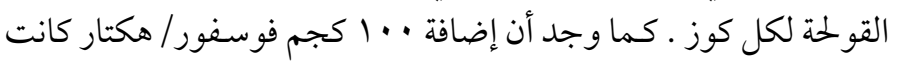

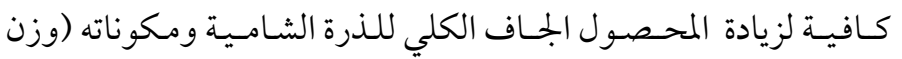

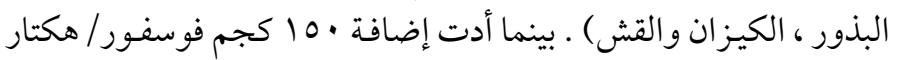

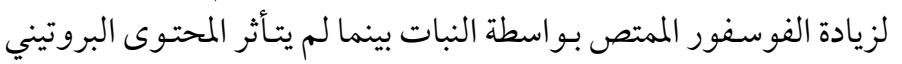

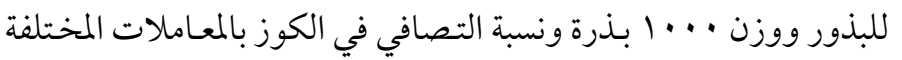

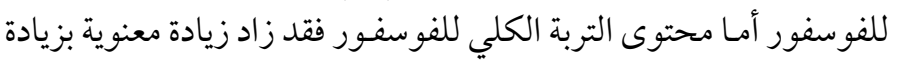

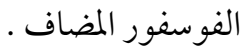

